Gruber, F. P., and Hartung, T. (2004). Alternatives to animal experimentation in basic research. ALTEX 21, Suppl., 3-31.

Knight, A. (2007). Systematic reviews of animal experiments demonstrate poor human clinical and toxicological utility. ATLA 35, 641-659.

Knight, A. (2008). Non animal methodologies within biomedical research and toxicity testing. ALTEX 25, 213-231.

Lindl, T., Weichenmeier, I., Labahn, D., et al. (2001). Evaluation von beantragten und genehmigten tierexperimentellen Versuchsvorhaben in Bezug auf das Forschungsziel, den wissenschaftlichen Nutzen und die medizinische Relevanz (Evaluation of authorised experiments on laboratory animals with regard to the aim of the research to be carried out, its scientific usefulness and its medical relevance). ALTEX 18, 171-178.

Lindl, T., Voelkel, M., and Kolar, R. (2005). Tierversuche in der biomedizinischen Forschung. Eine Bestandsaufnahme der klinischen Relevanz von genehmigten Tierversuchsvorhaben [Animal experiments in biomedical research. An evaluation of the clinical relevance of approved animal experimental projects]. ALTEX 22, 143-151.

Plous, S., and Herzog, H. (2001). Animal research. Reliability of protocol reviews for animal research. Science 293, 608609.
Pound, P., Ebrahim, S., Sandercock, P., et al. (2004). Where is the evidence that animal research benefits humans? BMJ 328 , 514-517.

Reines, B. P. (1991). On the locus of medical discovery. J. Med. Philos. 16, 183-209.

Rieser, T. M. (2005). Urinary tract emergencies. Vet. Clin. North Am. Small. Anim. Pract. 35, 359-373.

Toni Lindl ${ }^{1 *}$ and Manfred Voelkel ${ }^{2}$
${ }^{1}$ Institute of Applied Cell Culture,
Munich, Germany;
${ }^{2}$ Ethical Commission on Animal
Experimentation,
Wuerzburg, Germany
*Corresponding author:
Toni Lindl, PhD
Institut für angewandte Zellkultur
Balanstr. 6,81669 München
Germany
e-mail: I-A-Z@t-online.de

\title{
SATIS ethics ranking of universities in Germany regarding animal use in education
}

SATIS (latin: enough!) - the humane education project of People for Animal Rights Germany (PARG) - performed the first of its kind ethics ranking to assess the use of animals and need for alternatives in education and to create a guideline for highschool graduates and students, which is accessible at www.satistierrechte.de. We used a questionnaire-based telephone survey and called the responsible teachers for each course related to animal use at each faculty for biology, medicine and veterinary medicine in Germany to ask which animals or alternatives are used in practical classes and whether students have the possibility of conscientious objection. A university ranking was then established by means of specific ethical criteria.

Students of biology, medicine and veterinary medicine are often confronted with the use of animals for dissection or in physiological experiments. While future veterinarians and some biologists need hands on experience with animals, numerous high quality alternatives are available to avoid the harmful use of animals in education. These include models and mannequins, plastinated animals and animal body donation programs. A wide variety of alternatives is already established and evaluated in zoological institutes all over the world (see www.interniche.org; www.humanelearning.info). In this study, we were interested in the use of animals and alternatives at German universities.

The detailed questionnaire for teachers of zoological institutes asked which and how many animals are used in different courses, which alternatives are established and if not, whether students have the right to conscientious objection. Additional questions included the goals of the course using animals or alternatives, the fate of surviving animals after the course and whether there was interest in implementing alternatives. The four-page questionnaire was to be either be filled in by us during a telephone interview with the responsible teacher or sent to the teacher as a writeable pdf file by email. Contact details of responsible teachers and basic information on degrees and curricula were found in a systematic web search.

We contacted the responsible instructors of all 5 faculties for veterinary medicine, 35 medical faculties and 70 biological faculties in Germany. No teacher was ready to perform a detailed telephone interview because of time constraints or lack of interest. While one third of the teachers ordered the writable questionnaire, only four filled it in and returned it. Most information was gathered in shortened telephone calls concentrated on the 
Tab. 1: Extract of the Ethical Ranking, see online pdf at www.satis-tierrechte.de for full information

\begin{tabular}{|c|c|c|}
\hline $\begin{array}{l}\text { Humane education without harmful } \\
\text { animal use }\end{array}$ & $\begin{array}{l}\text { Courses including harmless } \\
\text { field studies or giving students the right } \\
\text { to conscientious objection }\end{array}$ & $\begin{array}{l}\text { Conservative animal use, including } \\
\text { invasive, harmful experiments }\end{array}$ \\
\hline $\begin{array}{l}\text { Bochum Fac. Medicine } \\
\text { Bonn B.Sc. Applied Biology } \\
\text { Frankfurt Fac. Medicine } \\
\text { Gelsenkirchen B.Sc. Molecular Biology } \\
\text { Hannover Fac. Medicine } \\
\text { Kaiserslautern B.Sc. Applied Life Science } \\
\text { Kiel Fac. Medicine } \\
\text { Kleve B.Sc. Bioscience and Health } \\
\text { Lüneburg B.Sc. Enviromental Science } \\
\text { Marburg Fac. Medicine } \\
\text { Münster Fac. Medicine } \\
\text { Witten/Herdecke Fac. Medicine }\end{array}$ & $\begin{array}{l}\text { Berlin Charité Fac. Medicine } \\
\text { Heidelberg Fac. Medicine } \\
\text { Vechta B.Ed. Biology } \\
\text { Würzburg B.Sc. Biology }\end{array}$ & $\begin{array}{l}\text { Aachen Fac. Medicine } \\
\text { Magdeburg Fac. Medicine } \\
\text { all } 5 \text { Fac. Veterinary Medicine } \\
\text { all B.Sc. Biology }\end{array}$ \\
\hline
\end{tabular}

most important questions like the use of animals and types of alternatives. $73 \%$ of the teachers were prepared to answer these basic questions. Five percent of all teachers showed a positive interest in the project and asked for advice and information.

To present our results we listed all information regarding each university, branch and discipline. We then evaluated the courses by ethical criteria and ranked the faculties accordingly (Tab. 1).

The German federal statistics of animals in experiments indicate an annual use of 60,000 animals in education (including postgraduate courses). Our survey shows that students of human medicine often use spare animals from institutional laboratories (rodents, frogs) and factory farming (chicks), while students of veterinary medicine mostly learn using large animals from abattoirs or euthanized pets from animal clinics. Biology students dissect different animal species and use especially invertebrates and frogs in physiological experiments. Our results, compared to earlier selective surveys of SATIS asking students for information, show a decrease in the use of animals only in institutes for human medicine. No degree not involving animal use exists for veterinary medicine or the bachelor of biology. Apart from minor accommodations, like passive working in groups, students cannot complete their studies as conscientious objectors. Several institutes use alternatives such as virtual labs or student self-experimentation, but the curricula, teaching goals and course contents form a confusing mosaic - clearly opposing the aspired harmonization of bachelor degrees in Europe.

The survey show the use of and need for alternatives, which could be an important input for producers of models, software or other material. For this reason, SATIS has started to establish working relationships with alternatives producers. We are also working at the political level to introduce conscientious objection into German law. The new EU Directive (2010/63/EU) and the German animal welfare law both require that existing alternatives are used and we are providing advice to academia on the implementation of alternative methods. This first ethical rank- ing of universities in the country will allow German students to make informed decisions on the universities they want to attend, based on which branches of study do not include harmful animal use. Unfortunately for students with strong ethical principles, not every desired degree can be acquired without harmful animal use. Instructors who showed interest in alternatives in the telephone survey will now be initial contact points for SATIS' future activities in implementing alternatives in education.

As the success of our survey depends in part on the online presentation of the project, we have relaunched our webpage www. satis.tierrechte.de on which we provide detailed insight into alternatives including publications, awards and links to databases. In close partnership with InterNICHE, the International Network for Humane Education, we translated the InterNICHE alternatives database into German, loan a variety of material for humane education for free, and offer freeware and cheap software for different disciplines. By advising teachers and administrations on implementing alternatives in education, we are improving the ethical and humane development of students and their motivation to start a career in the innovative field of non-animal research.

Astrid Schmidt* , Christiane Hohensee, Ute Teichgräber, and André Schmidt

People for Animal Rights, Aachen, Germany

*Corresponding author:

Astrid Schmidt, $\mathrm{PhD}$

People for Animal Rights Germany

Roermonder Str. 4a

52072 Aachen

Germany

e-mail: satis@tierrechte.de phone: +49(0)3641.229765 